\title{
Penehyclidine Hydrochloride Has the Function of Lung Protection for Acute Lung Injury in Rat Models:A Systemic Review and Meta-analysis
}

\section{Shasha Luo}

Hunan Normal University

Hongbao Tan ( $\square \tan 13755160707 @ q q . c o m$ )

Hunan Province, China

Li Chen

Brain Hospital of Hunan Province

Dongwei Wang

Hunan Normal University

Rong Hua

Hunan Normal University

\section{Research}

Keywords: Penehyclidine hydrochloride, Acute lung injury, Meta-analysis

Posted Date: September 14th, 2021

DOI: https://doi.org/10.21203/rs.3.rs-870781/v1

License: (c) (i) This work is licensed under a Creative Commons Attribution 4.0 International License. Read Full License 


\section{Abstract}

Objective

This systematic review and meta-analysis aims to review the effects of penehyclidine hydrochloride (PHC) on acute lung injury in animal models.

Methods

PubMed, Embase, CNKI were searched for collecting the randomized controlled trials(RCTs) on the effects of penehyclidine hydrochloride on acute lung injury in rat models from inception to July 1,2021 . We used Cochrane evaluating quality and RevMan 5.3 software performing Meta-analysis.(lung W/D ratio[

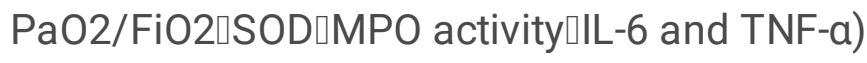

Results

Our search including 11 studies in 3 databases. Meta-analysis showed that, Compared with the acute

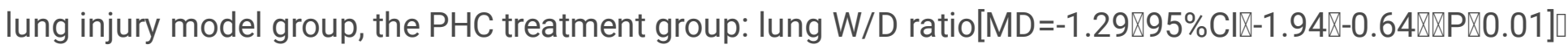

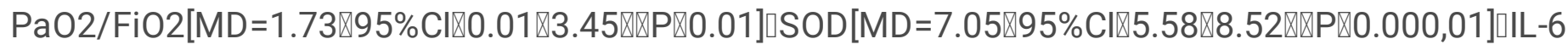


$\mathrm{a}[\mathrm{MD}=-2.17 \rrbracket 95 \% \mathrm{Cl} \rrbracket-3.27 \rrbracket-1.07 \rrbracket \otimes \mathrm{P} \rrbracket 0.0001]$.

Conclusions

penehyclidine hydrochloride has the function of lung protection in acute lung injury and provides a new therapy for future clinical treatment.

\section{Introduction}

Acute lung injury (ALI) is a continuum of lung changes caused by infection, collagen vascular diseases and shock. It is typically characterized by inflammatory changes, dyspnea, and refractory hypoxemia that typically presents finally as respiratory distress syndrome(ARDS), resulting in raised morbidity ${ }^{[1]}$.

Studies have found that the inflammatory mechanism is very important for ALI's occurrence and development ${ }^{[2-4]}$. Shock, oxidative stress and other factors can stimulate the production of upstream Tolllike receptor 4 (TLR4) factor, which can effectively start the inflammatory signal pathway ${ }^{[5]}$. After the activation of the NF-kB signal pathway, it can further induce the activation of downstream inflammatory cells, to produce the inflammatory cascade effect, so that the inflammatory process can be amplified and sustained. Finally, it acts on the lung tissue, leading to inflammatory injury ${ }^{[6,7]}$. Recent studies have found that the $\mathrm{PHC}$ has the function of lung protection and inflammation inhibitation ${ }^{[8,9]}$. Therefore, $\mathrm{PHC}$ is an alternative drug for the treatment of acute lung injury. However, its efficacy and mechanism have not been systematically evaluated and analyzed. Therefore, we evaluated the effect of PHC intervention 
through the Meta-analysis, in order to understand the therapeutic effect of PHC for acute lung injury in rat models.

\section{Methods}

\section{Study inclusion and Exclusion criteria}

inclusion criteria included1) Randomized Controlled Trial (RCT);2) animal studies; Languages: Chinese and English; 3) Languages: Chinese and English; 4) Intervention measures: The experimental group was penehyclidine hydrochloride treatment group, and the control group was the same amount of normal saline injection or other treatments alone.

Exclusion criteria included 1)incomplete experimental data and unclear experimental methods; studies published as review, case report or abstract; 2) Clinical trial research, reviews, case reports or retrospective analysis; 3) duplicate publications.

\section{Study quality assessment}

The Camaradesi list score was used independently by two authors(Shasha LUO and Dongwei Wang)to evaluate the methodological quality of trials. We discuss and resolve when there is a disagreement. The Camaradesi list scoring system(ranging from 1 to 10)includes; 1 )Sample size calculation $₫ 2 \bigotimes$ Randomization process; $3 \varangle \mathrm{B}$ lindedness model induction of acute lung injury; $4 \llbracket B$ lindedness assessment; 5) Appropriate mouse model; 6)Application the anesthetics do not significantly improve the degree of lung injury; 7)Control the temperature; 8)Published after peer review; 9)Comply with the animal protection law; 10区Declarate potential conflicts and interest.YES scores 1 point, NO does not score. Higher scores indicate exceptional methodologic qualities, and lower scores suggest poor qualities.

\section{Data abstraction}

Two authors extracted independently the included studies (research general information ,intervention and control measures, observation indicators and research results)and then checked them. The authors of the included studies were contacted if the information is not comprehensive.

\section{Statistical analysis}

All data were provided by utilizing RevMan (version 5.3 , Cochrane, $a=0.05$.), and all including studies were


is good $\left(P>0.10, I^{2}<50 \%\right)$; conversely,the random-effects model is used when the heterogeneity is statistically significant $\left(P<0.10, I^{2} \geq 50 \%\right)$.

\section{Results}


We searched 135 articles in 3 databases. Finally, 11 articles were included in the meta-analysis by reading the abstract and the main text.Document retrieval processes were presented in Figure 1.

\section{Characteristics of included studies}

1.Acute lung injury model

Most of the models are induced by injecting LPS or blunt chest trauma. Among the anaesthesia囚they

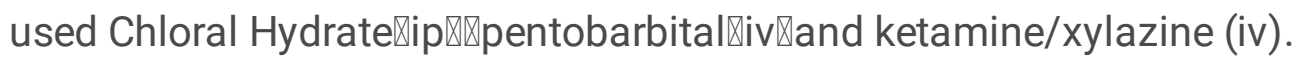

2.PHC intervene

$\mathrm{PHC}$ dosages ranged from $0.3 \mathrm{mg} / \mathrm{kg}$ to $5 \mathrm{mg} / \mathrm{kg}$. PHC was administered $30-60 \mathrm{~min}$ before model establishment . खAs shown in Table 1)

Table 1. data of the included studies $(n=11)$

\begin{tabular}{|c|c|c|c|c|c|c|}
\hline \multirow{2}{*}{ Study } & \multirow{2}{*}{ Acute lung injury model } & \multirow{2}{*}{ Anaesthesia } & \multicolumn{2}{|c|}{ PHC group } & \multirow{2}{*}{ Contol group } & \multirow{2}{*}{ Outcomes } \\
\hline & & & Dose & Timing & & \\
\hline \multirow{2}{*}{ Jia Zhan, 2011} & \multirow{2}{*}{ cecal ligation } & \multirow{2}{*}{ hloral Hydrate ( ip) } & $0.3 \mathrm{mg} / \mathrm{kg}$ & before ALI $1 \mathrm{~h}$ & Saline & \multirow{2}{*}{ (1), (4)、 (5) } \\
\hline & & & $0.4 \mathrm{mg} / \mathrm{kg}$ & before ALI $1 \mathrm{~h}$ & Saline & \\
\hline RongtaoZhu, 2018 & acute pancreatitis & chloral hydrate (im) & $0.2 \mathrm{mg} / \mathrm{kg}$ & 30 ain prior to ALI, & $\begin{array}{c}\text { Blank } \\
\text { sodium chloride }\end{array}$ & (3), (4), (5) \\
\hline Xiaojing $\pi u, 2019$ & $\begin{array}{l}\text { intratracheal } \\
\text { administra- }\end{array}$ & pentobarbital (iv) & $0.5 \mathrm{ml}(2 \mathrm{mg} / \mathrm{kg})$ & 30 ain prior to ALI & $\begin{array}{l}\text { Saline } \\
\text { Saline }\end{array}$ & (3), (4), (5) \\
\hline Zhaohui Liu, 2020" & induced renal ischemia & $\mathrm{NR}$ & $1 \mathrm{mg} / \mathrm{kg}$ & 30 min after ALI & Blank & (2). (3) \\
\hline \multirow[t]{2}{*}{ Shaobing Ye, 2020} & \multirow[t]{2}{*}{ " } & \multirow[t]{2}{*}{$\mathrm{NR}$} & $\begin{array}{c}0.5 \mathrm{mg} / \mathrm{kg} \\
1 \mathrm{mg} / \mathrm{kg}\end{array}$ & \multirow[t]{2}{*}{ prior to ALI } & PBS & \multirow[t]{2}{*}{ (2). (3) } \\
\hline & & & $2.5 \mathrm{ng} / \mathrm{kg}$ & & PBS & \\
\hline \multirow{3}{*}{ Junting Teng, 2019} & \multirow{3}{*}{ LPS } & \multirow{3}{*}{ Dentobarbital (iv) } & $1 \mathrm{mg} / \mathrm{kg}$ & lh & LPS & \multirow{3}{*}{ (2), (3), (4)、 (5) } \\
\hline & & & $2.5 \mathrm{mg} / \mathrm{kg}$ & $\mathrm{lh}$ & Lat & \\
\hline & & & $5 \mathrm{mg} / \mathrm{kg}$ & $\mathrm{lh}$ & Blank & \\
\hline Hao Li, 2011 & cecal ligation & ketamine(iv) & $0.45 \mathrm{mg} / \mathrm{kg}$ & $1 \mathrm{~h}$ after ALI & $\begin{array}{l}\text { saline } \\
\text { saline } \\
\text { Blank }\end{array}$ & (2). (3) \\
\hline \multirow[t]{2}{*}{ Na Tang, 2012} & \multirow[t]{2}{*}{ LPS } & pentobarbital (iv) & $\begin{array}{r}0.3 \mathrm{mg} / \mathrm{kg} \\
1 \mathrm{mg} / \mathrm{kg}\end{array}$ & $\begin{array}{l}1 \text { min folloxing ALI } \\
1 \text { nin folloxing ALI }\end{array}$ & saline & (4). (5) \\
\hline & & & $3 \mathrm{ng} / \mathrm{kg}$ & 1 nin folloring ALI & $\begin{array}{l}\text { saline containing } \\
\text { LPS }\end{array}$ & \\
\hline & $\ln 9$ & & $0.3 \mathrm{mg} / \mathrm{kg}$ & 30 ain prior to ALI & saline & \\
\hline Teifeng Shen, 2009 & LPS & pentobarbital (iv) & $1 \mathrm{ng} / \mathrm{kg}$ & 30 ain prior to ALI $=$ & gethylprednisolone & (1). (2), (3) \\
\hline & & & $3 n g / \mathrm{kg}$ & 30 ain prior to ALI, & saline & \\
\hline Qian Kong, 2019 & blunt chest trauma & pentobarbital (iv) & $2 \mathrm{mg} / \mathrm{kg}$ & 30 ain prior to ALI, & saline & (1) \\
\hline & & & $\begin{array}{l}2 \mathrm{mg} / \mathrm{kg} \\
0.3 \mathrm{mg} / \mathrm{kg}\end{array}$ & $\begin{array}{l}60 \text { min prior to ALI } \\
30 \text { min before ALI }\end{array}$ & $\begin{array}{l}\text { saline } \\
\text { LPS }\end{array}$ & \\
\hline Xiaopeng Tiang, 2020 & LPS & $\mathrm{NR}$ & $\operatorname{lng} / \mathrm{kg}$ & 30 min before ALI & & (4). (5) \\
\hline & & & $3 \mathrm{ng} / \mathrm{kg}$ & 30 min before ALI & saline & \\
\hline
\end{tabular}

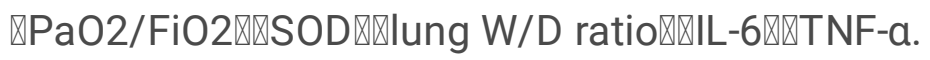




\section{Quality Evaluation}

1)Sample size calculation $\varangle 2 \varangle$ Randomization process; $3 \varangle B$ lindedness model induction of acute lung injury; 4『Blindedness assessment; 5) Appropriate mouse model; 6)Application the anesthetics do not significantly improve the degree of lung injury; 7)Control the temperature; 8)Published after peer review; 9)Comply with the animal protection law; 10खDeclarate potential conflicts and interest.YES scores 1 point, NO does not score. Higher scores indicate exceptional methodologic qualities, and lower scores suggest poor qualities.

Table 2. The Quality Evaluation of Eligible Studies $(n=11)$

\begin{tabular}{|c|c|c|c|c|c|c|c|c|c|c|c|c|}
\hline Study & & 1 & 2 & 3 & 4 & 5 & 6 & 7 & 8 & 9 & 10 & Score \\
\hline Jia Zhan & 2011 & & $\sqrt{ }$ & $\sqrt{ }$ & & $\sqrt{ }$ & $\sqrt{ }$ & & $\sqrt{ }$ & $\sqrt{ }$ & & 6 \\
\hline Rongtao Zhu & 2018 & $\checkmark$ & $\sqrt{ }$ & $\sqrt{ }$ & & $\sqrt{ }$ & $\sqrt{ }$ & & $\sqrt{ }$ & $\sqrt{ }$ & $\sqrt{ }$ & 8 \\
\hline Xiaojing Wu & 2019 & $\checkmark$ & & & & $\sqrt{ }$ & $\sqrt{ }$ & & $\sqrt{ }$ & & & 4 \\
\hline Zhaohui Liu & 2020 & & $\sqrt{ }$ & $\checkmark$ & & $\sqrt{ }$ & $\sqrt{ }$ & $\sqrt{ }$ & $\sqrt{ }$ & $\sqrt{ }$ & $\sqrt{ }$ & 8 \\
\hline Shaobing Ye & 2020 & $\checkmark$ & $\sqrt{ }$ & $\checkmark$ & & $\sqrt{ }$ & $\sqrt{ }$ & $\sqrt{ }$ & $\sqrt{ }$ & $\sqrt{ }$ & $\sqrt{ }$ & 9 \\
\hline Junting Teng & 2019 & $\checkmark$ & $\sqrt{ }$ & $\sqrt{ }$ & & $\sqrt{ }$ & $\sqrt{ }$ & $\sqrt{ }$ & $\sqrt{ }$ & $\sqrt{ }$ & $\sqrt{ }$ & 9 \\
\hline Hao Li & 2011 & $\sqrt{ }$ & $\sqrt{ }$ & $\sqrt{ }$ & & $\sqrt{ }$ & $\sqrt{ }$ & $\sqrt{ }$ & $\sqrt{ }$ & $\sqrt{ }$ & $\sqrt{ }$ & 9 \\
\hline $\mathrm{Na}$ Wang & 2012 & $\checkmark$ & $\sqrt{ }$ & $\checkmark$ & & $\sqrt{ }$ & $\sqrt{ }$ & $\sqrt{ }$ & $\sqrt{ }$ & $\checkmark$ & & 8 \\
\hline Weifeng Shen & 2009 & $\checkmark$ & $\sqrt{ }$ & $\sqrt{ }$ & & $\sqrt{ }$ & $\sqrt{ }$ & & $\sqrt{ }$ & $\sqrt{ }$ & & 7 \\
\hline Qian Kong & 2019 & $\checkmark$ & $\sqrt{ }$ & $\sqrt{ }$ & & $\sqrt{ }$ & $\sqrt{ }$ & $\checkmark$ & $\sqrt{ }$ & $\sqrt{ }$ & $\sqrt{ }$ & 9 \\
\hline Xiaopeng liang & 2020 & $\sqrt{ }$ & $\sqrt{ }$ & $\sqrt{ }$ & & $\sqrt{ }$ & $\sqrt{ }$ & $\sqrt{ }$ & $\sqrt{ }$ & $\sqrt{ }$ & $\sqrt{ }$ & 9 \\
\hline
\end{tabular}

\section{Meta analysis's result}

A.PaO2/FiO2هB.SOD囚C.lung W/D ratioهD.IL-6هE.TNF-a.

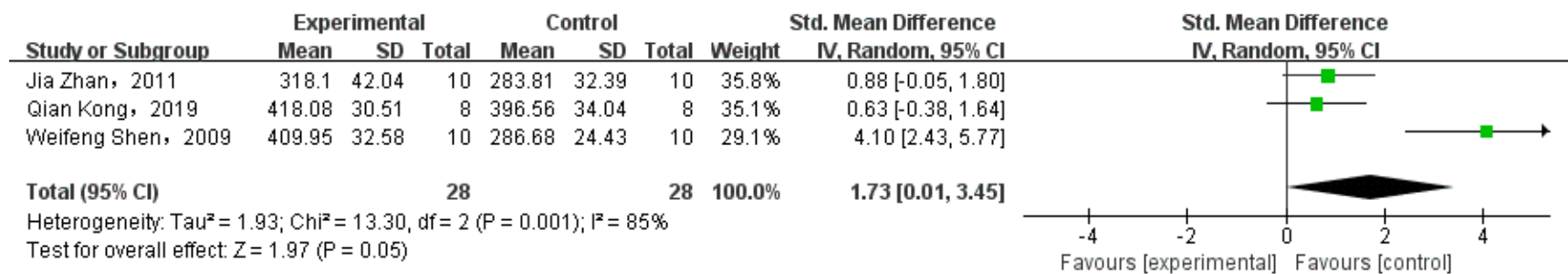

A

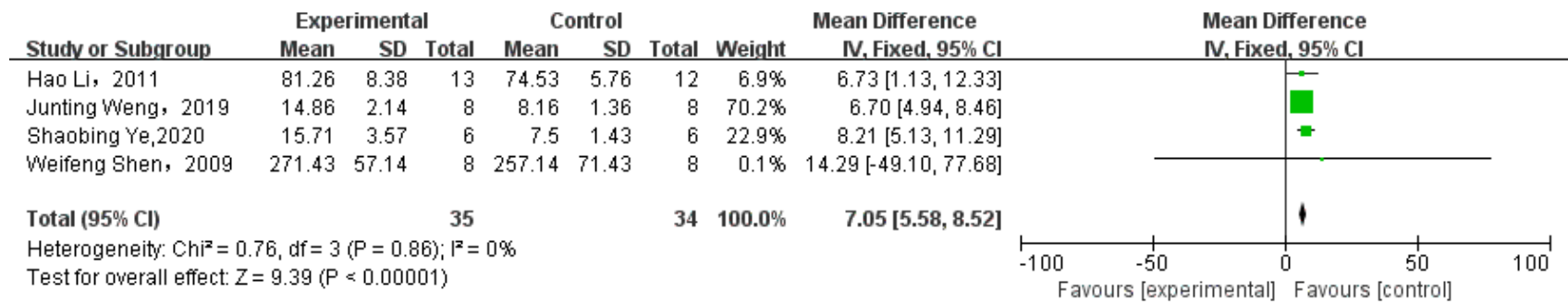




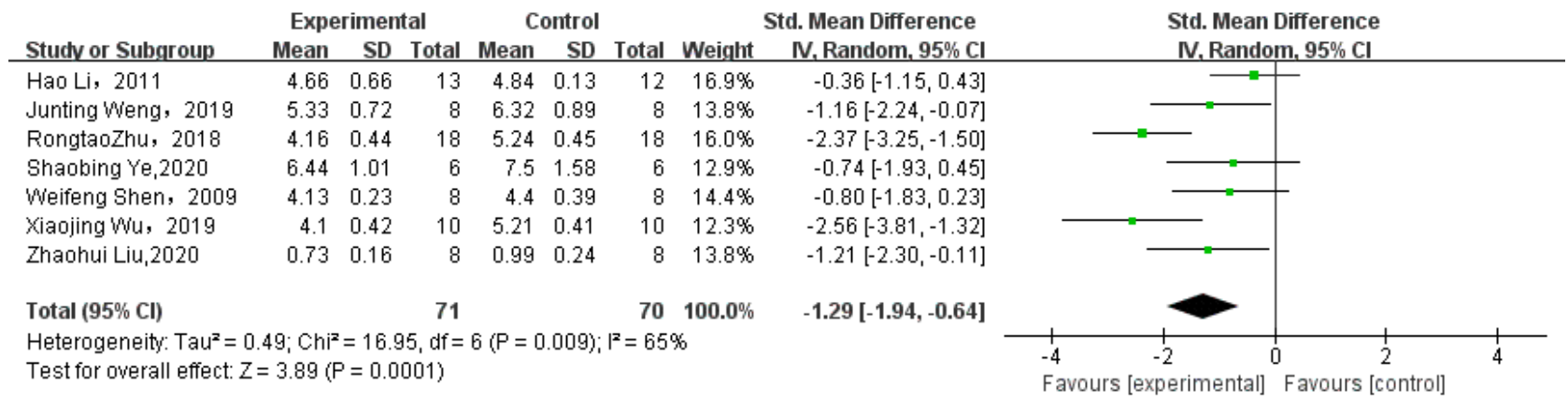

C

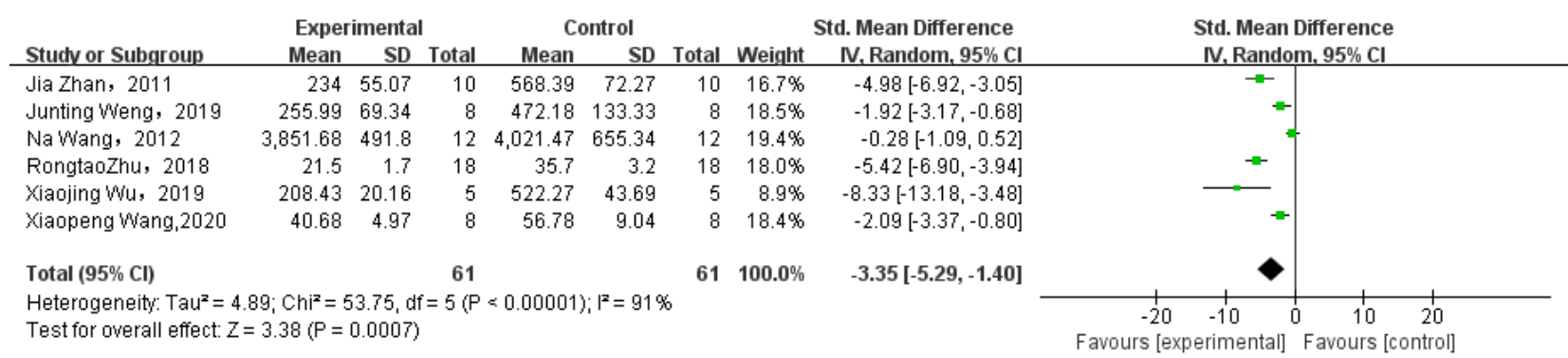

D

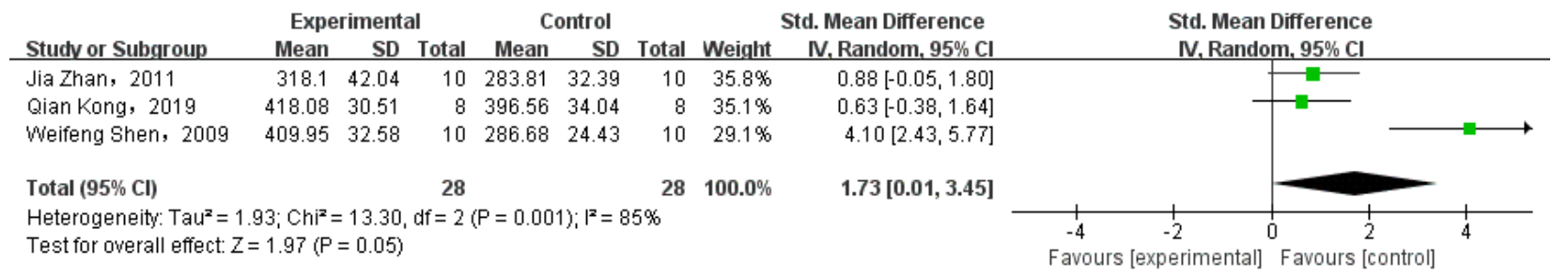

$\mathrm{E}$

\section{PaO2/FiO2}

This included 3 articles ${ }^{[10-12]}$ to evaluate lung function through applying Oxygenation Index. There was statistical heterogeneity between the results of each study $\left(I^{2}=93 \%, P<0.0001\right)$, so we used the randomeffects model. Compared with the control group, $\mathrm{PHC}$ affected on improving the oxygenation index of the lungs[RR=1.73, $95 \% \mathrm{Cl}(0.01,3.45), \mathrm{P}<0.01]$. ( Figure $\mathrm{A})$

\section{SOD}

This included 3 articles ${ }^{[12-15]}$ detected SOD in lung tissues. There was statistical heterogeneity between the results of each study $\left(I^{2}=80 \%, P<0.01\right)$. we excluded the articles(Zhaohui Liu, 2020) after sensitivity analysis, the heterogeneity disappears. Compared with the control group, $\mathrm{PHC}$ affected on improving the SOD.[ RR=7.05, 95\% Cl (5.58, 8.52), Pख0.00001] (Figure B) 
This included 7 articles ${ }^{[12-18]}$.Due to the different measurement units among the studies, we used the random-effects model. The lung wet-to-dry ratio of the $\mathrm{PHC}$ group is lower than the control group. $[\mathrm{MD}=-1.29,95 \% \mathrm{Cl}(-1.94,-0.64), \mathrm{P}<0.001]$ (Figure C)

\section{IL-6 and TNF-a}

This included 6 articles $^{[13-15,17,19,20]}$.Due to the different measurement units among the studies, we used random effects model. The IL-6 and level of the PHC group is lower than the control group. [IL6:MD=-3.35,95\% Cl(-5.29, -1.40), $\mathrm{P}<0.0001$; TNF-a:MD=-2.17,95\%Cl(-3.27, -1.07), $\mathrm{P}<0.01]($ Figure D口E)

\section{Discussion}

$\mathrm{ALI}$ is one of the most common clinical illnesses. With the development of the disease, it will threaten the life of patients and economic of society ${ }^{[21]}$. Therefore, it is very important for us to find a suitable treatment for ALI. Studies have shown that ALI is closely related to inflammation ${ }^{[2-4]}$. That is the reason why $\mathrm{PHC}$ is a good choice for the treatment of $\mathrm{ALI}$, which can reduce inflammation and protect the lung ${ }^{[8,}$ 9]. At present, the application of PHC in animal models of acute lung injury has become more popular. Our study aims to clarify the effect of PHC for acute lung injury in rat models and provides a new treatment.

This study reviews systematically the studies of acute lung injury in rat models treatment with $\mathrm{PHC}$ .Based on the current evidence, PHC treatment can significantly reduce the IL-6, TNF-a, and lung W/D ratio, it can also increase SOD and lung oxygenation index.So it has a good effect on the lungs. Although the results show that PHC is beneficial, the heterogeneity is not satisfactory. The analysis may have the following reasons: 1 . the quality of the included studies are not high; 2 . the dose and time of PHC are different; 3 . the rat species establish are different.

\section{Limitations of systematic reviews}

Although meta-analysis shows that PHC has certain advantages in acute lung injury treatment, the metaanalysis cannot replace multi-center RTC. In addition, we found that there are large differences in the mouse model ling methods, PHC doses, and PHC inject time. That is why the heterogeneity is not satisfaction. Therefore, we need more evidence support of double-blind RCT, and then select unified experimental standards. Only in this way our research results can be more reliable.

\section{Declarations}

\section{Authors' contributions}


revised and edited the paper. 
All authors read and approved the manuscript. The authors declare that all data were generated in-house and that no paper mill was used.

\section{Funding}

This research was supported by grant number 2020JJ8039 from

The Natural Science Foundation of Hunan Province .

\section{Conflict of interest}

The author declares that she has no conflict of interest.

\section{Availability of data and materials}

Not available.

\section{Ethics approval and consent to participate}

Not available.

\section{Acknowledgements}

Not available.

\section{Consent for publication}

The author consents to the publication of the manuscript in European Journal of Medical Research.

\section{References}

[1] Butt Y, Kurdowska A, Allen T C. Acute Lung Injury: A Clinical and Molecular Review[J]. Arch Pathol Lab Med, 2016,140(4):345-350.

[2] Xia W, Pan Z, Zhang H, et al. Inhibition of ERRalpha Aggravates Sepsis-Induced Acute Lung Injury in Rats via Provoking Inflammation and Oxidative Stress[J]. Oxid Med Cell Longev, 2020,2020:2048632.

[3] Li D, Ren W, Jiang Z, et al. Regulation of the NLRP3 inflammasome and macrophage pyroptosis by the p38 MAPK signaling pathway in a mouse model of acute lung injury[J]. Mol Med Rep, 2018,18(5):4399-4409.

[4] Ju M, Liu B, He H, et al. MicroRNA-27a alleviates LPS-induced acute lung injury in mice via inhibiting in fl ammation and apoptosis through modulating TLR4/MyD88/NF-kappaB pathway[J]. Cell Cycle, 2018,17(16):2001-2018. 
[5] $\mathrm{Hu} \mathrm{R}, \mathrm{Xu} \mathrm{H}$, Jiang $\mathrm{H}$, et al. The role of TLR4 in the pathogenesis of indirect acute lung injury[J]. Front Biosci (Landmark Ed), 2013,18:1244-1255.

[6] Tang J, Xu L, Zeng Y, et al. Effect of gut microbiota on LPS-induced acute lung injury by regulating the TLR4/NF-kB signaling pathway[J]. Int Immunopharmacol, 2021,91:107272.

[7] Todd B D, Godfrey L W, Bodley R N. Intraoperative radioactive localization of an osteoid osteoma: a useful variation in technique[J]. Br J Radiol, 1989,62(734):187-189.

[8] Wu X J, Liu H M, Song X M, et al. Penehyclidine hydrochloride inhibits TLR4 signaling and inflammation, and attenuates blunt chest trauma and hemorrhagic shock-induced acute lung injury in rats[J]. Mol Med Rep, 2018,17(5):6327-6336.

[9] Wang X, Liu F, Xu M, et al. Penehyclidine hydrochloride alleviates lipopolysaccharideinduced acute respiratory distress syndrome in cells via regulating autophagyrelated pathway[J]. Mol Med Rep, 2021,23(2).

[10] YanlinWang J Y Z C. Effect of penehyclidinehy drochloride on expressions of MAPK in mice with CLP-induced acute lung injury[J]. Mol BiolRep, 2011,38:1909-1914.

[11] Kong Q, Wu X, Duan W, et al. Penehyclidine hydrochloride exerts protective effects in rats with acute lung injury via the Fas/FasL signaling pathway[J]. Exp Ther Med, 2019,17(5):3598-3606.

[12] Shen W, Gan J, Xu S, et al. Penehyclidine hydrochloride attenuates LPS-induced acute lung injury involvement of NF-kappaB pathway[J]. Pharmacol Res, 2009,60(4):296-302.

[13] Li H, Qian Z, Li J, et al. Effects of early administration of a novel anticholinergic drug on acute respiratory distress syndrome induced by sepsis[J]. Med Sci Monit, 2011,17(11):R319-R325.

[14] JuntingWeng M Q J S. Penehyclidinehy drochloride defend sagainst LPS-induced ALI in rats by mitigating endoplasmic reticulum stress and promoting the Hes1 Notch1 pathway[J]. Gene, 2019,721.

[15] ShaobingYe M X M Q. Penehyclidine Hydrochloride Alleviates Lipopolysaccharide-Induced Acute Lung Injury by Ameliorating Apoptosis and Endoplasmic Reticulum Stress[J]. Journal of surgical research, 2020,245:344-353.

[16] Zhu R, Zhao Y, Li X, et al. Effects of penehyclidine hydrochloride on severe acute pancreatitisassociated acute lung injury in rats[J]. Biomed Pharmacother, 2018,97:1689-1693.

[17] Wu X, Kong Q, Xia Z, et al. Penehyclidine hydrochloride alleviates lipopolysaccharideinduced acute lung injury in rats: Potential role of caveolin1 expression upregulation[J]. Int J Mol Med, 2019,43(5):20642074. 
[18] Liu Z, Li Y, Yu L, et al. Penehyclidine hydrochloride inhibits renal ischemia/reperfusion-induced acute lung injury by activating the Nrf2 pathway[J]. Aging (Albany NY), 2020,12(13):13400-13421.

[19] Wang N A, Su Y, Che X M, et al. Penehyclidine ameliorates acute lung injury by inhibiting Toll-like receptor 2/4 expression and nuclear factor-kappaB activation[J]. Exp Ther Med, 2016,11(5):1827-1832.

[20] Wang X, Liu F, Xu M, et al. Penehyclidine hydrochloride alleviates lipopolysaccharideinduced acute respiratory distress syndrome in cells via regulating autophagyrelated pathway[J]. Mol Med Rep, 2021,23(2).

[21] Tsushima K, King L S, Aggarwal N R, et al. Acute lung injury review[J]. Intern Med, 2009,48(9):621-630.

\section{Figures}


135 of records identified through database

searching:Pubmed( $n=23) ; \operatorname{EMBASE}(n=26) ; \mathrm{CNKI}(n=86)$

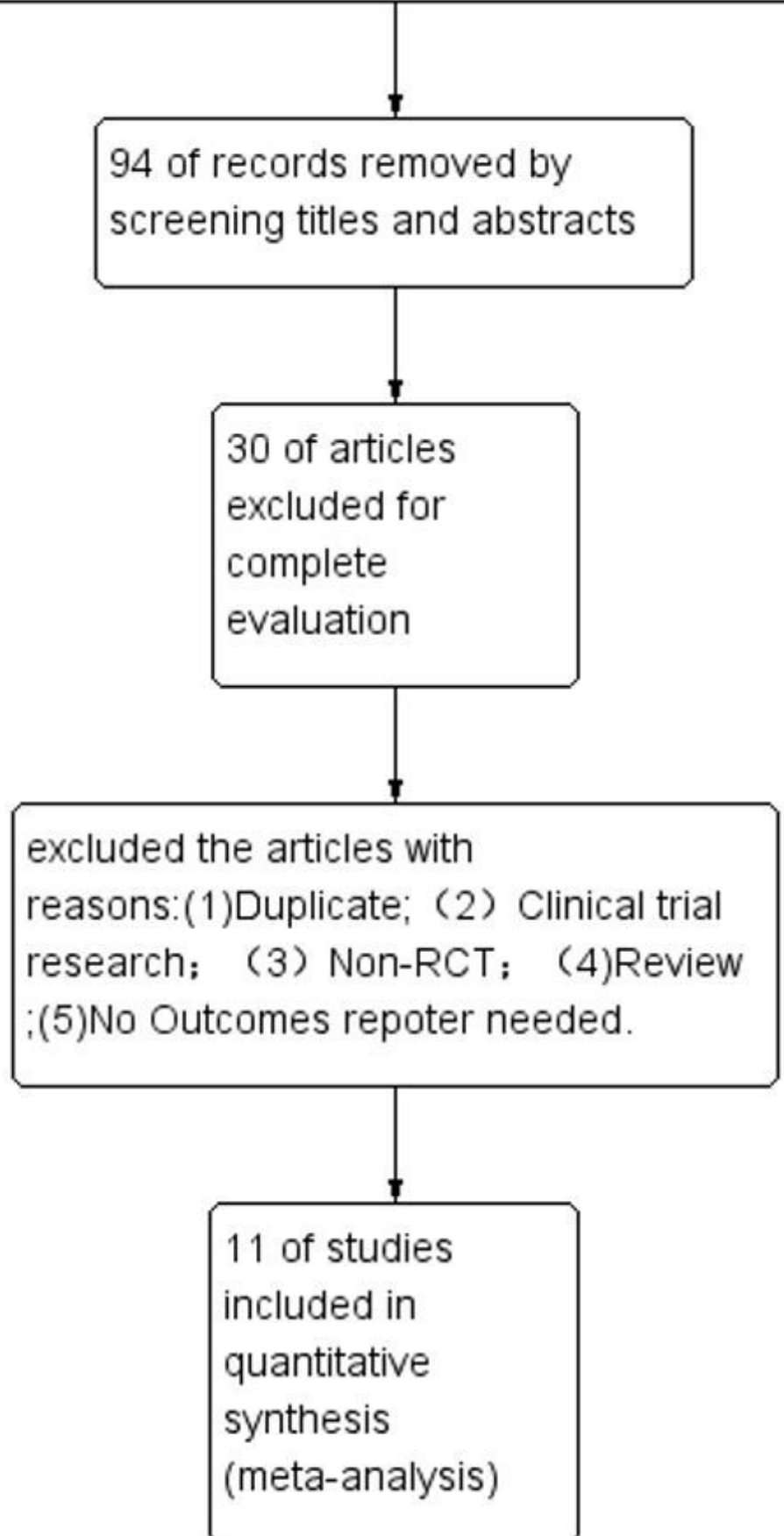

Figure 1

Flow chart of literature selection. 